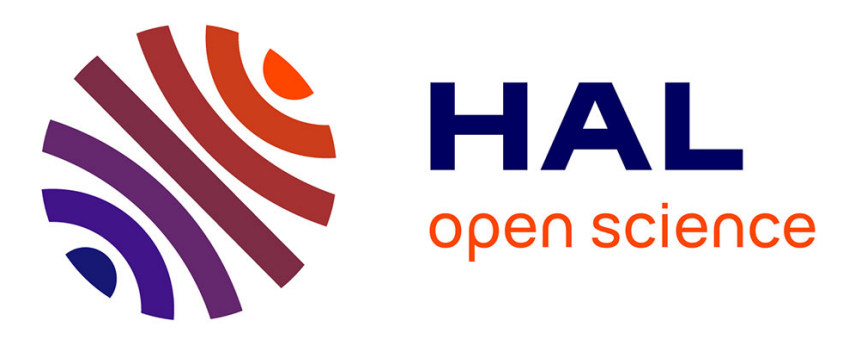

\title{
Chemical and biochemical engineering for a new sustainable process industry in Europe
}

\author{
Martine Poux, Nicolas Roche
}

\section{To cite this version:}

Martine Poux, Nicolas Roche. Chemical and biochemical engineering for a new sustainable process industry in Europe. Chemical Engineering Research and Design, 2016, Chemical Engineering Research and Design, 115 (Part B ), pp.261. 10.1016/j.cherd.2016.10.037 . hal-01458420

\section{HAL Id: hal-01458420 \\ https://hal-amu.archives-ouvertes.fr/hal-01458420}

Submitted on 17 Feb 2017

HAL is a multi-disciplinary open access archive for the deposit and dissemination of scientific research documents, whether they are published or not. The documents may come from teaching and research institutions in France or abroad, or from public or private research centers.
L'archive ouverte pluridisciplinaire HAL, est destinée au dépôt et à la diffusion de documents scientifiques de niveau recherche, publiés ou non, émanant des établissements d'enseignement et de recherche français ou étrangers, des laboratoires publics ou privés. 


\section{Editorial}

\section{Chemical and biochemical engineering for a new sustainable process industry in Europe}

The very title itself was the slogan of the main scientific event in Chemical Engineering in Europe, held in Nice in September 2015, which combined the 10th European Congress of Chemical Engineering (ECCE10), the 3rd European Congress of Applied Biotechnology (ECAB3) and the 5th European Process Intensification Conference (EPIC5). These events were organised by the French Society of Chemical Engineering (SFGP) and Live! By GL under the auspices of the European Federation of Chemical Engineering (EFCE) and the European Society of Biochemical Engineering Sciences (ESBES).

The conference focused on four main societal challenges:

- Energy: new and unconventional resources, conservation and management

- Water management and treatment

- Biotechnology and food

- Industrial ecosystems

and addressed fundamental chemical and biochemical engineering research.

Approximately 1800 people from all around the world (67 nationalities) attended the conference. The participation of industrialists (25\%) and students (31\%) was highly remarkable. The scientific program was impressive, being composed of 5 symposia, 4 workshops, 6 plenary lectures, 82 keynotes and more than 700 oral communications organised in 202 sessions and 900 poster communications. These covered vast chemical and biochemical engineering topics, which reflected the latest scientific trends in their field.

For the first time in the history of this congress, a number of novel student events, including a student quiz, a thesis competition, a jobs forum and a breakfast meeting with senior researchers, was organised over the five days. These were greatly appreciated by the students, leaving them with unforgettable memories.
The exhibition area welcomed 39 companies in a very beautiful and pleasant space that was highly favourable for fruitful exchanges.

Several special issues of different peer-reviewed journals featuring selected papers from the congress will ultimately be published. This special issue of Chemical Engineering Research and Design collects 17 manuscripts which were pre-selected by the topic managers of the sessions devoted to Mixing \& Multiphase flow; Computer-Aided Engineering - Process System Engineering; and Fluid Separation.

\section{Acknowledgements}

We wish to thank everyone involved in the organization of this congress, the topic managers and all the members of the scientific committee as well as all the sponsors who have supported the events and especially the topic managers who have worked on this special issue, Jerzy Baldyga, Xavier Joulia and Michel Meyer.

Martine Poux ECCE10-ECAB3-EPIC5 General Coordinator, Laboratory of Chemical Engineering (LGC), Toulouse University - Institut National Polytechnique, Toulouse, France Nicolas Roche

ECCE10-ECAB3-EPIC5 Coordinator, Coordinator Interdisciplinary and Intersectoral Research Pole (PR2I) "Environment", Aix-Marseille University - Aix-en-Provence, France E-mail addresses: Martine.Poux@ensiacet.fr (M. Poux), nicolas.roche@univ-amu.fr (N. Roche)

0263-8762/@ 2016 Published by Elsevier B.V. on behalf of The Institution of Chemical Engineers.

http://dx.doi.org/10.1016/j.cherd.2016.10.037 